\title{
Evaluation of the Innovated Disinfection Process with High Dissolved $\mathrm{CO}_{2}$
}

\author{
Xuehang CHENG*, Tsuyoshi IMAI*, Junki YAMAGUCHI*, Tawan LIMPIYAKORN** \\ and Alissara REUNGSANG*** \\ * Graduate School of Science and Engineering, Yamaguchi University, 2-16-1, Tokiwadai, \\ Ube, Yamaguchi, 755-8611, Japan \\ ** Faculty of Engineering, Chulalongkorn University, Bangkok, 10330, Thailand \\ *** Faculty of Technology, Khon Kaen University, Khon Kaen, 40002, Thailand
}

\begin{abstract}
A novel high-dissolved $\mathrm{CO}_{2}$ device was developed for the disinfection of treated sewage wastewater. Several experiments were conducted regarding the waterborne pathogen inactivation rate, the treatment time and the disinfection target (several treated sewage wastewaters, canal and river water). The results indicated that different disinfection targets can lead to 2.8-3.0 loginactivation of waterborne pathogens within 20 minutes of treatment under $0.3 \mathrm{MPa}$ of pressure in the device. Results also showed that the suspended solid (SS) in raw water affected the disinfection efficiency.
\end{abstract}

Keywords: disinfection, high dissolved $\mathrm{CO}_{2}$, liquid film

\section{INTRODUCTION}

Disinfection has become a challenging aspect of water treatment because of the rapid elevation of health standards and the growing concern for pollution free water resources. Coagulation-membrane filtration (Fiksdal and Leiknes, 2006), UV radiation (Hijnen et al., 2006), and ozone associated processes (Rennecker et al., 1999; Jyoti et al., 2004; Rashmi et al., 2007) have been developed as new disinfection technologies to replace chlorination disinfection due to its toxic and carcinogenic by-products (Steve, 2009) and the invalidation of some chlorine-resistant protozoan, such as Cryptosporidium (Kristen et al., 2000) and Giardia (Lawryshyn and Cairng, 2003). However, the high construction costs and operation expenses have become problems that prevent their use in practical applications. Therefore, an innovative disinfection process using highdissolved $\mathrm{CO}_{2}$ was developed to minimize the operating cost and provide a free byproduct effect. This process is a new concept differing from high pressure $\mathrm{CO}_{2}$ disinfection (Laura et al., 2005) and supercritical $\mathrm{CO}_{2}$ disinfection (Ishikawa et al., 1997; Kobayashi et al., 2007; Liao et al., 2007).

In this paper, treated sewage wastewater (both in Japan and Thailand), canal water (Thailand) and river (Thailand) water were used as targets for the disinfection to confirm the disinfection effects in practical applications. The relation between inactivation rates of the fecal coliforms (FC) and total coliforms (TC) (the indicator waterborne pathogen) as well as the treatment time were examined. Additionally, other factors affecting the $F C$ and $T C$ inactivation rates were also discussed.

Address correspondence to Tsuyoshi Imai, Graduate School of Science and Engineering, Yamaguchi University, Email: imai@yamaguchi-u.ac.jp

Received December 23, 2009, Accepted April 26, 2010. 


\section{MATERIALS AND METHODS}

\section{Disinfection mechanism}

The high-dissolved $\mathrm{CO}_{2}$ device is shown in Fig. 1. To improve the contact efficiency between $\mathrm{CO}_{2}$ and water, the nozzle with a small radius was set to provide influent at a high rate. When the influent stroked the bottom of the device, many liquid films (bubbles) were produced, and as a result, the $\mathrm{CO}_{2}$ dissolution rate increased because of the larger gas-liquid contact area.

Inside the device, the microorganism uptake the $\mathrm{CO}_{2}$ dissolved in the water because of the existence of the $\mathrm{CO}_{2}$ concentration difference between the inside (low) and outside (high) of the cell. When the water was discharged outside the device, the pressure suddenly decreased, while the $\mathrm{CO}_{2}$ inside the cell appeared and caused a large amount of bubbles quickly, resulting in a rupture of the microorganism. Additionally, the $\mathrm{CO}_{2}$ penetrating into the microorganism was able to alter the properties of the cells (Dixon and Kell, 1989). Therefore, disinfection in this study can be defined as microorganism inactivation.

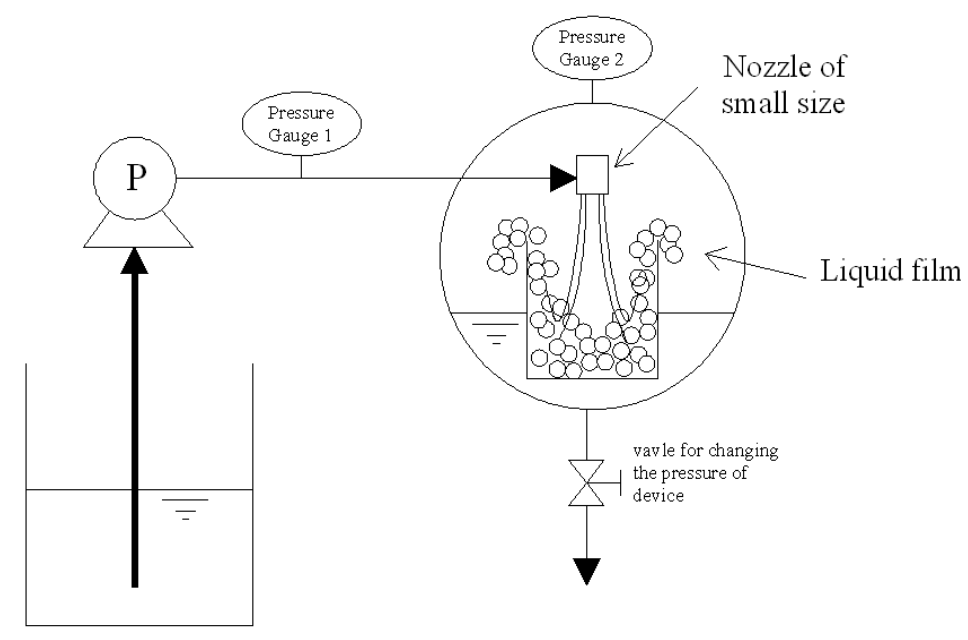

Fig. 1 - Mechanism of the high-dissolved $\mathrm{CO}_{2}$ device

\section{Disinfection experiment}

The effluent from the final settling tank of a wastewater treatment plant (WWTP) as well as canal water and river water were used as targets for disinfection in this study. During this study, one set of operational conditions was applied for the device, as shown in Fig. 2. $\mathrm{CO}_{2}$ was filled the device before the experiment; the water cycled in $20 \mathrm{~min}$ after it was pumped into the device; and the samples were taken at different times.

\section{Analytical procedures}

Enumeration of bacteria was done by plate count method as recommended by Japan Sewage Works Association (JSWA, 1997). This method of analysis has been used for the estimation of the overall reduction in the colony forming units (CFU). For this purpose, desoxycholate agar was used as the growth medium. The samples before and after treatment suitably diluted was introduced into each Petri dish first and then $10 \mathrm{~mL}$ of media was added and mixed, after they turned into solid, another $10 \mathrm{~mL}$ of media was added. For $F C$ count, these Petri dishes were inverted and incubated at $44.5^{\circ} \mathrm{C}$ for $18-20$ 
$\mathrm{h}$; For $T C$ count, these Petri dishes were inverted and incubated at $37^{\circ} \mathrm{C}$ for $18-20 \mathrm{~h}$. The colonies developed were counted and expressed as $\mathrm{CFU} / \mathrm{mL}$. The data presented are the means with standard errors of the results of experiments performed in several sessions The log survival ratio $\left(\log _{10}\left(\mathrm{~N} / \mathrm{N}_{0}\right)\right)$ was calculated to determine the final inactivation effect, where $\mathrm{N}_{0}$ was the number of initial microorganisms in the untreated sample, and $\mathrm{N}$ was the corresponding viable number of microorganisms after treatment. Suspended solid (SS) and volatile suspended solid (VSS) were analyzed by Standard methods for water and wastewater analysis (APHA, 1989), TOC was analyzed by TOC-5000 (SHIMADZU, Japan).

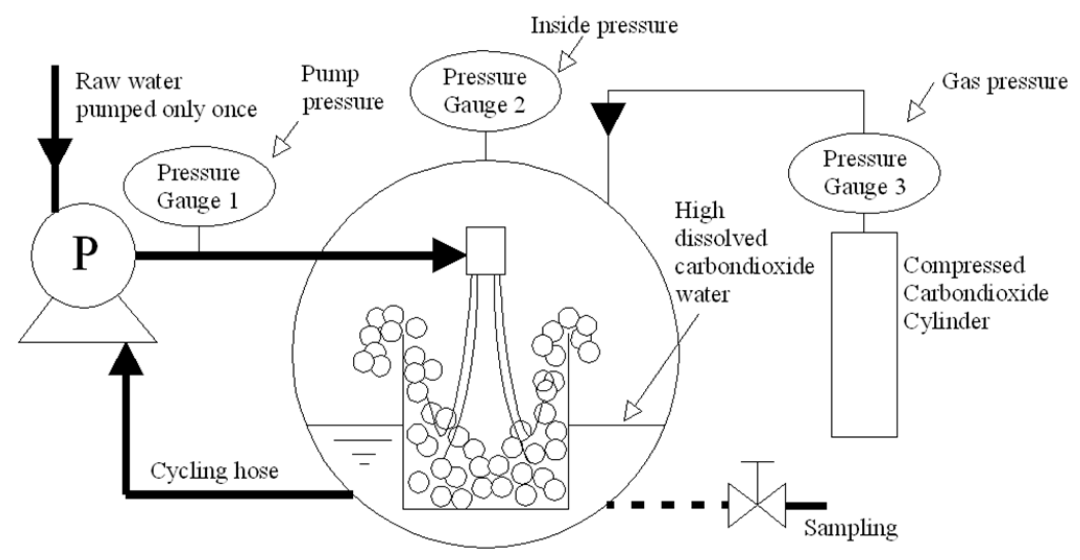

Fig. 2 - Device operating conditions

\section{RESULT AND DISCUSSION \\ Optimization of operating conditions}

The effluent from the final settling tank of a WWTP (Ube City, Japan) used as the target for disinfection was treated under different pressures. The experiment was repeated for two months. The average results are shown in Fig. 3 and show that $T C$ only achieved a 1.2 log-inactivation under $0.2 \mathrm{MPa}$ of pressure for $20 \mathrm{~min}$. However, a $2.0 \mathrm{log}$ inactivation of $T C$ occurred quickly under $0.5 \mathrm{MPa}$ and $0.4 \mathrm{MPa}$ of pressure in $10 \mathrm{~min}$. Additionally, under $0.3 \mathrm{MPa}$ of pressure, $T C$ log-inactivation reached 2.7-3.0. Therefore, the operational condition of $0.3 \mathrm{MPa}$ for $20 \mathrm{~min}$ was selected because the lowest pressure achieved the highest TC log-inactivation. Also, compared to the supercritical $\mathrm{CO}_{2}$ method, which requires pressures as high as 8-20 MPa (Ishikawa et al., 1995), this method saved lots of energy. In addition, when compared to the high pressure process for disinfection, which requires a long duration of pressure leading to the deformation of the cell (Laura et al., 2005), the method used in this study saved operation time. 


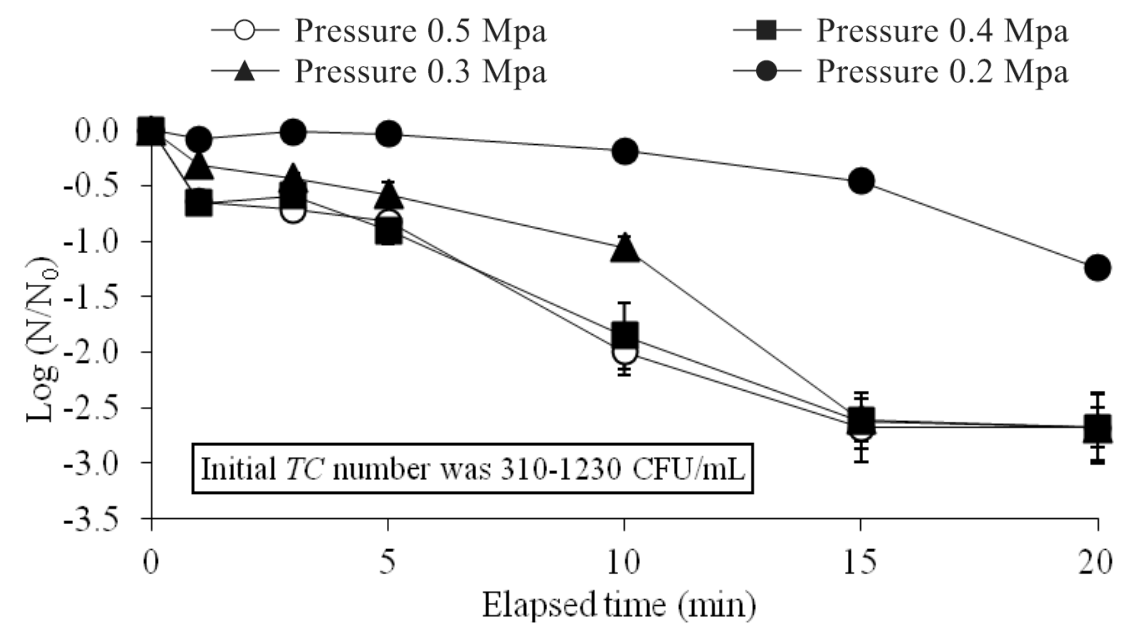

Fig. 3 - Inactivation of $T C$ under different inside pressures in the device. (Each data point is an average of independent experiment and error bars represent the data range.)

\section{Disinfection effect of different initial FC}

Experiments were conducted at least twice, with several effluents from the final settling tank of the WWTP (Table 1), at the operational condition of $0.3 \mathrm{MPa}$ of pressure. WWTP1 had a $F C$ log-inactivation as high as 1.5 in $10 \mathrm{~min}$. However, it took time for the other two samples to increase the $F C$ log-inactivation in $10 \mathrm{~min}$, but after $10 \mathrm{~min}$, the $F C \log$-inactivation quickly increased. The reason for these results is that these two samples had more initial $F C$ numbers, and $10 \mathrm{~min}$ was not long enough for all of the bacteria to uptake enough $\mathrm{CO}_{2}$, which lead to the explosion of all cells when discharged outside of the device. Based on these results, we speculated that lower initial microbial numbers could quickly achieve high disinfection effects.

Table 1 - Water quality of different WWTP final settling tank effluents in Thailand

\begin{tabular}{|c|c|c|c|c|c|}
\hline Place & SS (mg/L) & VSS (mg/L) & TOC $(\mathrm{mg} / \mathrm{L})$ & $F C(\mathrm{CFU} / \mathrm{mL})$ & Sample \\
\hline Din Deang WWTP & 3.41 & 2.38 & 5.52 & $940 \pm 20$ & WWTP1 \\
\hline Si phraya WWTP & 5.36 & 4.64 & 5.11 & $1300 \pm 45$ & WWTP2 \\
\hline Chong Nonsi WWTP & 5.73 & 3.08 & 6.86 & $2400 \pm 120$ & WWTP3 \\
\hline
\end{tabular}




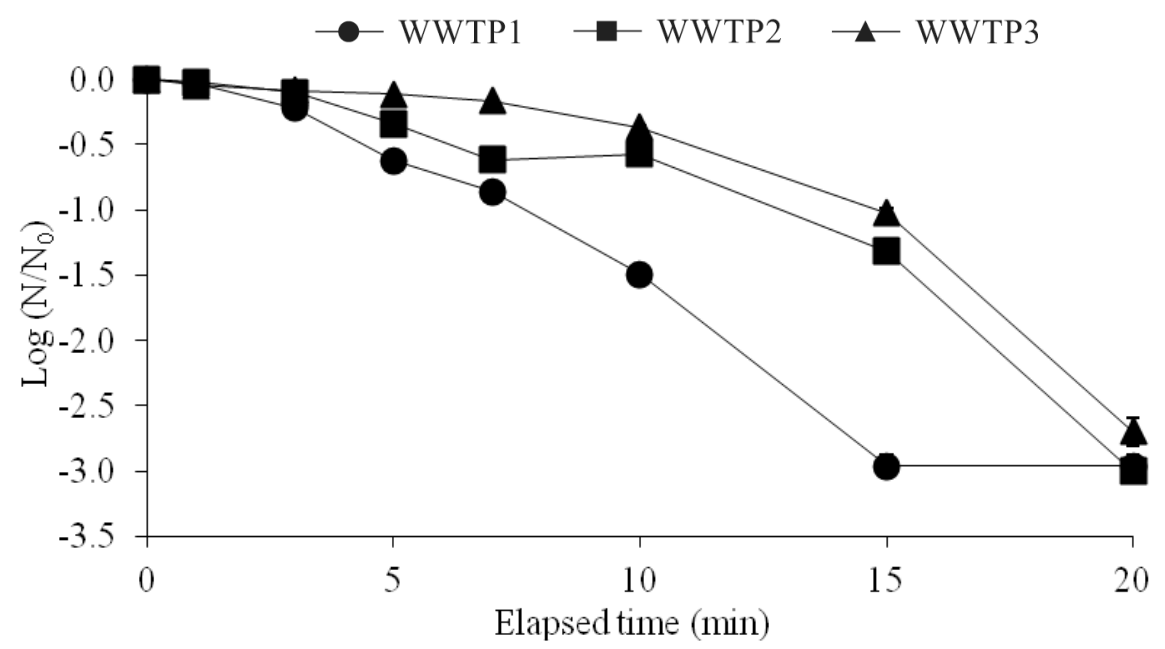

Fig. 4 - Inactivation of $F C$ from different WWTP final settling tank effluents. (Each data point is an average of independent experiment and error bars represent the data range.)

\section{Disinfection effect of different suspended solids concentrations in raw water}

As shown in Fig. 5, canal water 1 and the river water (Table 2) shared lower initial FC numbers compared to the WWTP samples, but the $F C$ log-inactivation was lower than 0.4 in the first $10 \mathrm{~min}$, then quickly increased after $10 \mathrm{~min}$. One reason for this result could be that the higher SS in the canal and river waters inhibited the uptake of $\mathrm{CO}_{2}$ by the bacteria, leading to the slower $F C$ inactivation. The results also revealed that it was possible to reach a high $F C$ log-inactivation of 2.8 for the canal and river waters in 20 min. Canal water 2 contained a very high initial $F C$ number, and the $F C$ log-inactivation was relatively flat due to the high initial $F C$ number that inhibited the effects of the SS.

Table 2 - Water quality of different canal and river water in Thailand

\begin{tabular}{|c|c|c|c|c|c|}
\hline Place & $\begin{array}{c}\mathrm{SS} \\
(\mathrm{mg} / \mathrm{L})\end{array}$ & VSS (mg/L) & TOC (mg/L) & FC (CFU/mL) & Sample \\
\hline Pathuntani Klong 5 & 11.6 & 2.26 & 9.55 & $72 \pm 8$ & $\begin{array}{c}\text { Canal } \\
\text { water 1 }\end{array}$ \\
\hline $\begin{array}{c}\text { Khlong Phadung Krung } \\
\text { Kaseme }\end{array}$ & 33.6 & 13.4 & 13.0 & $35000 \pm 550$ & Canal \\
\hline $\begin{array}{c}\text { Chao Phraya River } \\
\text { (Largest river in } \\
\text { Bangkok) }\end{array}$ & 17.7 & 2.08 & 7.73 & $690 \pm 30$ & River water \\
\hline
\end{tabular}




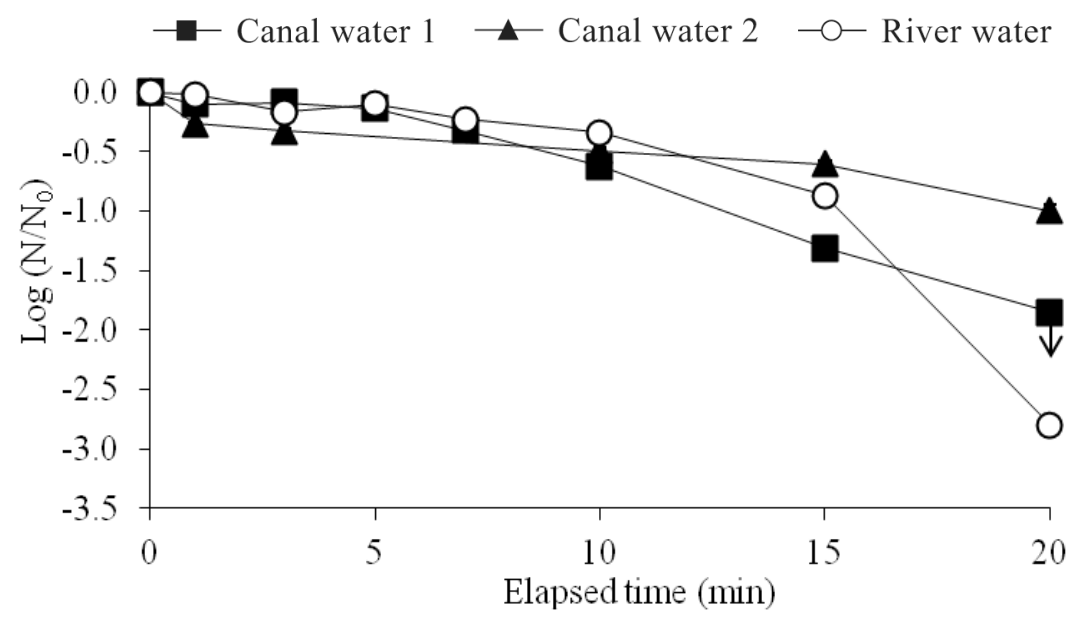

Fig. 5 - Inactivation of $F C$ for different canal and river waters. (Each data point is an average of independent experiment and error bars represent the data range. $\downarrow$ : No colony was detected, the log inactivation was suggested more than this point.)

To be sure of the effect of SS in raw water, another experiment was conducted with the supernatant from the final settling tank of the WWTP (Ube City, Japan) with the same initial TC numbers, but with different SS concentrations. The average results shown in Fig. 6 indicate that high SS samples resulted in lower $T C$ log-inactivation in the first 10 min. Especially, the highest SS sample ( $\mathrm{SS}=20.9 \mathrm{mg} / \mathrm{L}$ ) showed no $T C$ inactivation between 5 and $10 \mathrm{~min}$. It was speculated that bacteria buried in the SS inhibited the speed of $\mathrm{CO}_{2}$ uptake into their cells. However, after $10 \mathrm{~min}$, the $T C \log$-inactivation quickly increased, and it was thought the continuous bubbling released the bacteria buried in the SS, allowing the bacteria to take up $\mathrm{CO}_{2}$ again. From these results, after 20 min, the $T C$ log-inactivation of the two samples could not reach 2.67 (result of SS = $1.67 \mathrm{mg} / \mathrm{L}$ ). The results also demonstrated that low SS in the target water produced greater disinfection efficiency. 


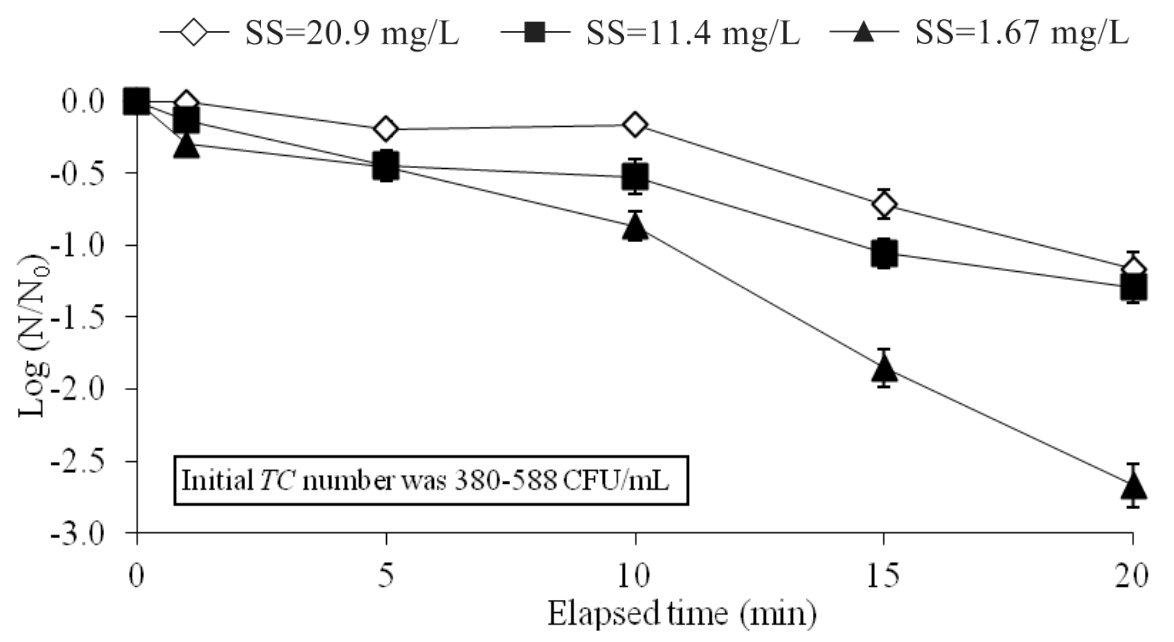

Fig. 6 - The relationships between $T C$ inactivation and the treatment time with different SS. (Each data point is an average of independent experiment and error bars represent the data range.)

\section{CONCLUSION}

(1) The optimum operational condition of the device is a pressure of $0.3 \mathrm{MPa}$. When a high-dissolved $\mathrm{CO}_{2}$ device is used for the disinfection of the effluent from the final settling tank in a WWTP, the TC log-inactivation was as high as 3.0 in $20 \mathrm{~min}$.

(2) $F C$ log-inactivation could be as high as 2.8 for canal and river water disinfection. In addition, the disinfection efficiency would increase if it is possible to remove the SS from the raw water.

\section{REFERENCE}

APHA (American Public Health Association) (1989). Standard methods for the Examination of Water and Wastewater, AWWA and WCPC, Washington D.C

Dixon N. M. and Kell D. B. (1989). The inhibition by $\mathrm{CO}_{2}$ of the growth and metabolism of micro-organisms, J. Appl. Bacteriol., 67, 109-136.

Fiksdal L. and Leiknes T. (2006). The effect of coagulation with MF/UF membrane filtration for the removal of virus in drinking water, J. Membr. Sci. 279(1-2), 364371.

Hijnen W. A., Beerendonk E. F. and Medema G. J. (2006). Inactivation credit of UV radiation for viruses, bacteria and protozoan oocysts in water: A review, Water Res., 40(1), 3-22.

Ishikawa H., Shimoda M., Tawano T. and Osajima Y. (1995). Inactivation of Enzymes in an Aqueous Solution by micro bubbles of supercritical Carbon Dioxide, Biosci. Biotech. Biochem., 59, 628-631.

Ishikawa H., Shimoda M., Tamaya K., Yonekura A., Kawano T. and Osajima Y. (1997). Inactivation of bacillus spores by the supercritical carbon dioxide micro-bubble method, Biosci. Biotech. Biochem., 61(6), 1022-1023.

JSWA (Japan Sewage Works Association) (1997). Standard methods for the examination of sewage wastewater (Japanese), Tokyo, Japan, 698-718.

Jyoti K. K. and Pandit A. B. (2004) Ozone and cavitation for water disinfection. Biochem. Eng. J., 18(1), 9-19.

Kobayashi F., Hayata Y., Kohara K., Muto N. and Osajima Y. (2007). Application of 
supercritical $\mathrm{CO}_{2}$ bubbling to inactivate E.coli and colifrom bacteria in drinking water, Food Sci. Technol. Res., 13(1), 20-22.

Kristen M. R., Jason L. R. and Benito J. M. (2000). Inactivation of Cryptosporidium parvum oocysts with chlorine dioxide, Water Res., 34(3), 868-876.

Laura W. M., Malco C. R., Joseph P. K., Mark L., Margaret F. P., Mary S. and Alan, L. K. (2005) High pressure processing of shellfish: A review of microbiological and other quality aspects, Innovative Food Sci. \& Emerging Tech., 6(3), 257-270.

Lawryshyn, Y. A. and Cairns, B. (2003). UV disinfection of water: the need for UV reactor validation, Water Sci. and Tech.:Water Supply, 3(4), 293-300.

Liao H. M., Hu X. S., Liao X. J., Chen F. and Wu J. H. (2007). Inactivation of E.coli inoculated into cloudy apple juice exposed to dense phase carbon dioxide, International Journal of Food Microbiology, 118, 126-131.

Rashmi C., David H. B., Kyu C. N., Phillip J. C. and Parag R. G. (2007). Water disinfection using the novel approach of ozone and a liquid whistle reactor, Biochem. Eng. J., 35, 357-364.

Rennecker J. L., Marinas B. J., Owens J. H. and Rice E. W. (1999). Inactivation of Cryptosporidium parvum oocysts with Ozone, Water Res., 33(11), 2481-2488.

Steve E. H. (2009). Chlorination disinfection by-products, public health risk tradeoffs and me, Water Res., 43(8), 2057-2092. 